\title{
Determining the degree of reality of language
}

\author{
Jesus Martinez del Castillo \\ Department of Philology, Faculty of Business Studies and Tourism, Universidad de Almería, Almería, Spain
}

Email address:

jesus.gerardo@ual.es, apofansis@msn.com

\section{To cite this article:}

Jesus Martinez del Castillo. Determining the Degree of Reality of Language. International Journal of Language and Linguistics. Special Issue: Linguistics of Saying. Vol. 3, No. 6-1, 2015, pp. 39-49. doi: 10.11648/j.ijl1.s.2015030601.16

\begin{abstract}
Speakers live language, that is, they intuit, create, acquire, perform, speak and say, interpret, use, evaluate and, even, speak of language. The real language is the language lived by speakers. On the contrary linguists, who at the same time are speakers and linguists, study language as something manifesting of front of them. In order to study language it is necessary to determine the degree of reality of the thing called language as the reality lived and used by speakers.
\end{abstract}

Keywords: Real Language, The Language Used by Speakers, The Concept of Language, Mode of Thinking, Mode of Being

\section{Introduction}

In order to study the living reality of language it is necessary to determine what is the reality or degree of reality of the concepts and words we use when studying language. Our purpose is to formulate a theory on it. A theory of language must be real, that is, adequate to real language, the language spoken.

The problem consists in guessing if language can be verified or what aspects of language can be verified. If language can be verified then it must exist. On the contrary, we shall have to find out the reality on which the reality of the thing we call language is based on. All the aspects used and manifest in the verbal behaviour of speakers, namely, language, a language, speaking or the activity of speaking, speech and speech acts, refer to different realities. They all converge and manifest in the reality we call language.

\section{The Problem}

In order to study language it is necessary to pose the problem in the most radical position, neglecting anything previously accepted. We cannot accept the concepts manifesting themselves in the verbal behaviour of speakers, because they refer to partial aspects of the problem. The base they are founded on must be determined through analysis. The base on which they all stand on is to be called, according to Ortega y Gasset1, the radical reality.

1 Cf. Ortega y Gasset, 1996, pp. 40-41.
The question now is: does "language" refer to the living reality of language, that is, the language spoken? Can language be verified? What is the reality or degree of reality of language?

\section{Connections in the Concepts Involved in the Verbal Behaviour of Speakers}

At first sight we cannot say that language exists, since language cannot be verified in itself but only in the indefinite number of executions it has. Language is necessary for speakers to speak in general, to speak in a particular language, to speak individually, to speak about things, to express ideas, thought, to speak to one another, to understand things and the world, to speak scientifically, to make science, and even to speak about language itself and linguistics. Language is necessary for us to create words, concepts, things, the world, our conscience as human beings, and even to analyse language itself. In this sense, language manifests itself as speaking or the activity of speaking.

But if we compare language with speaking, at first sight we shall see that language cannot be verified; speaking can, but only to a certain extent. In order to understand speaking we must refer its reality to language as a concept; on the contrary speaking would be nothing. The only thing in the verbal behaviour of speakers we can verify is speech acts. So far we can only draw the following conclusion: language and speaking do not have the same degree of reality. They are very similar to each other, but they constitute two different realities, not independent from each other. Language is something in speakers, but for language to exist there must be the activity of 
speaking, and for the activity of speaking to exist there must be speech acts. Language manifests itself in speaking and speech acts.

However, speaking exists because language determines speaking. This means that if we want to understand the activity of speaking we must refer it to the concept of language. If language did not exist, the activity of speaking would not exist either. In this sense language is the condition for speaking to be.

But the problem still persists: we cannot verify language nor do we know what speaking consists in. Speaking thus constitutes a type of activity evincing something beyond it, that is, speaking is not anything independent. Language thus is the determining thing and speaking the thing determined. Because of this we can consider the activity of speaking as the most genuine manifestation of language but nothing else.

\section{The Manifestation of Language}

On the other hand, language and the activity of speaking manifest themselves differently. They depend on the many speech communities existing in the world. The different speech communities constitute what we call a particular language or the different languages. Both language and the activity of speaking manifest themselves in the different languages existing in the world. Conceptually the particular language is prior to speaking. So language manifests itself in a particular language and both language and a particular language manifest themselves in speaking and speaking in speech acts. The degree of reality of these four concepts differs considerably. They all coexist at the same time in the same speech act. For language to be given, these three aspects must be given as well. With this we have a new aspect never to be forgotten in the analysis of language. Language, a particular language and the activity of speaking cannot be considered independent from speech acts. If speakers separate these four aspects, especially the first three ones, they must constitute mental realities, that is, aspects given together, never to be separated unless through analysis and abstraction. Language exists, that is, manifests itself as the creation of meanings. A particular language manifests itself as something virtual and common, the idiomatic knowledge of speakers. But speaking exists because of language and the particular language, thus manifesting itself in speech acts.

There is then a process of determination and implication: speech acts are determined by the activity of speaking. Speaking is determined with language and the particular language (=a language), and the particular language is determined with language. Language thus is absolute, cognizant activity, that is, creative activity, something mental and transcendent, a type of activity that can never be predicted or achieved in full, always aiming at achieving something else. On the contrary, a particular language cannot be absolute, it is contingent and historical, something made in history with the participation of all those who speak in a particular speech community. A particular language exists as something participated and common in a speech community, thus constituting the only base for the separation of the different groups of people and society to exist. Language is something mental, cognizant activity; a particular language is mental as well but virtual, participated, common and historical (=made in history), something given in a speech community. A particular language exists as the virtual knowledge in force in a speech community. In this sense a particular language is abstract but at the same time it is objective: it has form in sounds and contents. On the contrary language is pure creation: it has no established forms. But again we know all this manifesting itself in speaking. So when we say language, a particular language and speaking, we relate to three different concepts, any of them involving different degrees of reality, they all co-existing in the reality usually known as language thus manifesting in the verbal behaviour of speakers.

\section{Cognizant Connections}

Since we can conceive of the reality usually referred to as language and cannot verify it directly, we can say that language, as an act of knowing, is something constituted by at least four different realities: language, a particular language, speaking and speech acts. As a consequence we can say that language, a particular language, speaking and speech acts constitute nothing but aspects or cognizant connections speakers as cognizant subjects impose on the fact that people speak. But this fact is not a simple one: those who speak, that is, human subjects are cognizant, saying and speaking subjects. Speaking subjects speak because they have something to say and they say something because they are able to know. Speaking, saying and knowing are but three different aspects in a single and unique reality. In their deepest origin knowing is first: it is the starting point of the speech act. Saying is the real motor, that is, the determining factor founded on human nature, that is, freedom and historicity. Human subjects would not exist if they did not have anything to say2; and speaking involves both saying and knowing.

But this distinction is basically conceptual: separating aspects is something proper of analysis, especially in an act of knowing. Science is nothing but an act of knowing justified in full. Reality is multifaceted: it manifests itself in many perspectives imposed on the things it is constituted with. The act of knowing and the act of making science consists in imposing perspectives and connections on things surrounding us thus constituting reality. Reality is nothing but the possibility of imposing series of knots of connections 3 on the things in the circumstance human subjects are in 4, thus constituting things and accepting the conditions imposed by things on us. As a consequence to study reality, explaining things, means imposing perspectives and connections in what human subjects apprehend using language. Once these relationships have been imposed by means of language, the act

\footnotetext{
2 Cf. Ortega y Gasset, , 2001, p. 245.

3 Ortega y Gasset, 1982, p. 214

4 Ortega y Gasset 1994, p. 190.
} 
of knowing and science consist in separating and analysing reality into things. In this sense all sciences depend on language. Every branch of science has to create its own set of words or terminology to tackle with the things it studies. So the way of studying something and especially analysing it, means conceiving of it anew in a justified manner. This new conception with the analysis implicit in the way it is justified, constitutes science.

Since the set of things referred to as language is nothing but systems of perspectives and connections imposed on the fact that people speak, we can see, together with the relationships of determination said above, the following ones. Saying determines speaking and speaking is possible because of knowing. Saying is nothing but the definition of the subject before the circumstance he is in. Speaking is nothing but the manifestation of both saying and knowing. These two processes of determination (a process from the determining thing to the determined one) and implication (a process from the thing implied (determined) to the one implying (determining), evince the nature of language, language is something conceived of by humans, the result of an act of knowing, something mental and thus real in so far as it is mental.

\section{Language as it is Lived by Speakers}

The reality of language based on the fact that people speak, is a complex one. Language is something lived and created by free cognizant subjects who perform the complex activity of speaking, saying and knowing. Speaking is nothing but the activity to know, think, create and understand things and a world made up of things on the part of those free cognizant subjects. Free cognizant subjects create the world and the things in it just because they have something to say, that is, because they define themselves before the circumstance they are in, thus constituting things and compromising on the things constituted. And this is possible just because they know. Free cognizant subjects are creators in a double sense. They create both internally and externally. Internally they create their own self, that is, they create their consciences and the contents in it. Free cognizant subjects in this way become human: they know about things and at the same time they discover their own being as something different from the things known. This constitutes a defining feature separating human beings from non-human beings. Because of this human knowledge is different from animals' knowledge. Human subjects are free when, after perceiving, they transform the thing perceived into something different. Human perception and all types of perception are sensitive. But in the case of humans, freedom determines human perception and they will soon transform the sensitive into abstract. And free cognizant

5 The philosophical concept of "conscience" is the set of ideas, beliefs and contents in general constituting the 'self' of a human being, something different from the psychological concept of "consciousness", opposing its contrary, unconsciousness, a state in which we are aware. subjects create externally, that is, they create things and a world constituted of things through language and the means provided by language and the particular language.

Since language is the result of an act of knowing we can say that the reality of language is both abstract and concrete. It is abstract, because it is the result or an act of knowing; and it is concrete, since language is speaking, that is, language exists in the speech of speakers.

\section{Language as an Activity}

An activity is nothing in itself. It is something made by $a$ free subject thus involving three factors: the agent (the speaking subject), something being made, the product, and $a$ technique to make the thing involved. An activity without any consideration to the agent, the thing made and the product cannot even be understood. They all are necessary.

But here the essence or consistency of an activity lies. An activity cannot be but human. In human beings it is necessary to separate two types of actions: human activities and actions made naturally by humans. Human activities are free, capable of being performed only by human subjects because they are free and intelligent. For example, driving, painting, playing an instrument, writing, speaking, etc. On the contrary, natural actions have a biological function. They are necessary from a biological point of view. Only the first ones are human. Human beings however try to humanize all actions even natural actions. For example, it is peculiar of human beings to "adorn" eating with many other activities not necessary for the biological function of assimilating food for surviving. In human beings all actions and activities pass through the filter of intelligence and freedom6. A human activity thus is a free activity, an activity the existence of which exclusively depends on an intelligent free subject.

In the activity of speaking the agent is, needless to say, a cognizant free subject, the speaking subject, who, because he is free, is able to know and say something thus defining himself before the thing said. The speaking subject is not a mere speaking subject but a cognizant, saying and speaking subject. Because of this that free agent is creative. The cognizant, saying and speaking subject is an agent able to choose his purposes. His purposes constitute something non-defined, indefinite and infinite. Because of this, these purposes are necessarily individual.

The thing done is speech and the technique is the technique in the activity of speaking. And in this we have a process of determination as well: the cognizant, saying and speaking subject determines the technique of speaking, and because of the technique of speaking the speaking subject produces speech.

In this process of determination, the linguistic freedom of speakers manifests itself in the three factors stated in the activity of speaking. Cognizant, saying and speaking subjects are necessarily free because they have to do something in the

6 Coseriu 1988, 194 and 196. 
circumstance they are in with imaginative solutions. This means that they are necessarily individual. Because they are free and individual they are absolute, that is, creative, absolute and transcendent. As a consequence the technique of every individual speaker will be different. This proves the character of idiomatic knowledge: it is something learnt creatively from other speakers. Since idiomatic knowledge is participated, a particular language is nothing absolute but contingent, that is, historical, something made in history. As a matter of fact there are many languages. Diversity in language is something necessary. This emphasizes the fact already stated in linguistic determination: it is free determination. And finally, the thing done, that is, speech proves the variety of language and the freedom of speakers.

The determination of speech by the different techniques in the activity of speaking makes us believe that language is something homogeneous in a speech community. Since language is unique and the performance of speech individual, language is something common in a speech community, that is, something participated, something abstracted from speech. The problem has to do not with speech in so far as it is determined by free speaking, saying, cognizant subjects. Human subjects are free, absolute, and transcendent but at the same time they are together-with-others 7 , that is, they participate with others in the very creation of speech. Because of this they share forms, contents, rules, procedures, attitudes and beliefs with their co-speakers. Human subjects thus are historical and social, that is, they made themselves in history, living in a group of humans because they speak the same language, thus forming society. Because of this speech, that is, the performance of language is different in the different speech communities, that is, language manifests itself differently in the different languages in the world.

Because of the different processes of determination stated so far, we can say that language is all and at the same time mental, abstract, transcendent, virtual, objective, material, common, participated, historical and real. It is mental, that is, the creation of meanings, something universal. It is abstract, in a double sense: first as something made arbitrarily by the free, creative and cognizant subjects, and second as the model abstracted from speech acts by speakers and used by them to re-create it. That is, language is abstract at the level of creation (universal level) and abstract at the level of reconstituting the language (the particular or historical level). It is transcendent, since it goes beyond words and contents. It is virtual, since it is constituted by the idiomatic knowledge of speakers, something belonging to both the individual subject and the speech community. In this sense it is common as well, that is, participated and historical. It is objective, because it always manifests itself in forms, that is, in contents manifesting themselves in sounds (words and expressions). And it is real in the innumerable speech acts ever produced by individual subjects in particular innumerable circumstances and contexts used with the purpose of achieving something.

7 Cf. Coseriu, 1985 p. 31; Coseriu 2006, p. 27.
A speech act is at the same time individual and social. It is individual, since it is the expression of an intuition by a free, creative and cognizant subject at the moment of speaking. And it is social, since the free, creative and cognizant subject uses common forms, contents, rules, procedures, attitudes and beliefs belonging to the speech community, thus transforming them and making them participated. The free, creative and cognizant speaking subject does not create his expression in full but he rather re-creates his expression in accordance with previous models8.

So then, the conclusion we can draw from this initial foray into the problem of reality of language is that in order to study language we must analyse four different realities in language:

1. Language, something universal existing in the minds of speaking subjects or speakers as the creation of meanings;

2. A particular language or a historical language, something virtual, the idiomatic knowledge of speakers manifesting itself as common and participated;

3. Speaking or the activity of speaking, something involving the speaker, speech and the technique of speaking; and

4. Speech acts, both individual and social.

\section{Determining the Reality of Language as Universal}

When we set to study what we as speakers understand with the word 'language' the first problem we can pose, is whether language exists or, if it does, how it exists. Language cannot be verified in itself. We can verify that someone speaks, that many people speak, that babies cannot speak at the beginning but soon they will start bubbling at a particular moment, and then they will progressively speak sooner or later. The first conclusion we can draw from these facts is that language is something developed in a human being independent from any other ability. Language goes together with the growth of a human being but it is nothing to be verified directly in an effective way.

In consonance with this, based on analogy, we may conclude that language belongs to the human nature. Since human beings have a body and based, once again on analogy with other beings having a body, that is, with animals, we could consider that nature in human beings is something structural in them. That is, human beings are born with a particular kind of nature and language with it. With this we could interpret language as something depending on that kind of nature in humans. In this sense we could say that everybody past infancy and omitting serious pathology can speak9. We can carry on with this reasoning and conclude that all human beings are born with language. And then we may feel entitled to refer to this fact with a new name: language is as a faculty ${ }^{10}$.

8 Coseriu, 1986, p. 31.

9 Cf. Chomsky, 2000, pp. 77-78.

10 Cf. Chomsky, 2002, p. 47; Chomsky, 2002. p. 87. 
But in stating this, the only foundation for language to be is that it is founded on nature in the way conceived of earlier. Moreover, the problem is not solved in this way. Nature can be conceived of in a different way when dealing with human beings, that is, free and historical subjects. Nature can be conceived of as something cultural, that is, as something to be made by the human subject in the circumstance he is in 11 , nothing structural, previously made or given to us. A human being has to do something ${ }^{12}$ in the circumstance he is in. $\mathrm{He}$ will do either this or that but he will always select what to do freely. Since at the same time the human subject is together-with-another-on ${ }^{13}$ he will use forms either invented by him or participated with others. In this sense, a human subject has no nature, but instead he will have history14. In this sense human nature is nothing already made but something to be made in the circumstance human beings are, thus projecting it into the future. Language and the human nature have nothing to do with human bodies. Human bodies merely constitute the first circumstance human beings are involved in ${ }^{15}$.

But with the reasoning stated above, we did not analyse the reality of language, but synthesized, that is, we added something not contained in the concept "language". We started with the concept given to us by our language, which, since it is expressed with a noun, involves the existence of the reality denoted as something existing in itself. But this is nothing but the belief that "language exists in itself". Then we added the concept of nature and concluded that language was something in the structural nature of human beings. And since it was something in the human nature we added as well that it should be a faculty. So the question whether language exists or not and thus is real, was not answered but neglected and assumed it to be true.

If we accepted that reasoning as a statement, ('language is a natural faculty'), we could see the following implication: language appears in it, in the mere statement of it, as something existing. The only thing we do in the statement is stating that it is a faculty. Now then, if language (the subject of the statement) did not exist we would not be able to say anything of it. The problem, when we want to determine the degree of reality of something, consists merely in determining the connection it has with the real. If we assume that language exists beforehand we can say it can be verified, it is real. But we didn't previously verify it. Then, it would be a petitio principii, that is, solving the problem because of the terms posed in the formulation of it. In cases like these Karl Popper proposes denying the statement 16 . If the negation of the statement does not present contradiction in its terms but is

\footnotetext{
11 Ortega y Gasset 1994, p. 190

12 Ortega y Gasset 1999, 119-120.

13 Coseriu 1985, 206.

14 Ortega y Gasset says: "a man has no nature: nothing in him is invariable. Instead of nature he has history, something no other creature in the world has. History is the peculiar way of being of an entity whose essence is variation" (Ortega y Gasset, 2003, p. 125).

15 Cf. Ortega y Gasset 2002, p. 49.

16 Cf. Popper, 2002, p. 5.
}

logically possible it is real. So the negation of the statement, 'language is not a natural faculty', is not logically possible since we conceive of the subject (language) as something existing. If it exists it is something other than a faculty; thus the statement is false. We wanted to verify the degree of reality of language, that is, if language existed or not, and came back to the starting point: assuming that language is. As a consequence this reasoning does not prove what we wanted to.

On the other hand, if we accepted that statement, we would accept the original conception of language and nature by naïve speakers in western languages. If we wanted to solve the problem of language and thought, the problem would be to define, not language, but nature. On the contrary, it would mean excluding thought from language.

But we cannot accept the existence of language as existing in itself since language cannot be verified in itself. We can only verify the fact that people speak. The fact of adding new notes or characteristics to the act of knowing (or conceiving of) language, does not guarantee the reality of the fact involved in it. Just the contrary: we have to demonstrate the existence of language and thus its degree of reality, first, and then conclude about the nature of the existence of language. The conclusion that language is (or is not) a faculty, cannot be based on the concept of language just because this is the problem, as I said above. The problem is just to justify language and determine the degree of reality of it.

The concept "language" has to do with the fact that people speak; considered in this sense it is real. But this is nothing but paraphrasing the content of it. Since the fact referred to deals with an activity performed by human beings, and only by human beings, the concept of language is to be conceived of as something defining them. Since human beings are free and thus absolute and transcendent, language is creative, absolute and transcendent, and since human beings speak to say something, language is the creation of the things executed by speakers, that is, language is nothing but the creation of meanings, contents of conscience by human beings. Language is thus the representation of the condition of being of human beings. Human beings are free because they manifest themselves in language when language is being created, that is, when human beings speak.

The concept of language as something absolute is nothing unless it is referred to those who speak. To say language is to say what human beings do in order to survive in the circumstance they are in at any moment. Language, then, does not exist. It exists in so far as it states what human beings are and do in the circumstance they are in. Language without any direct reference to human beings cannot constitute the base to formulate a theory. Language cannot constitute the radical reality we we are looking for. 


\section{Language as the Linguistic Expression of Something Necessary}

So the problem in determining the degree of reality in things is words and the conception of things, both re-arranged in statements. Reality and the words designating reality constitute something created by human beings in language. This is so because we, as human beings, cannot perceive reality directly but indirectly. We perceive reality in accordance with our senses. Our senses are sensitive because they are concrete and can perceive only sensitively. Our senses give us, each one in its proper peculiarity, a concrete image of what it is. Then we transform what comes up through our senses into something the contrary to concrete, something non-concrete, that is, mental, abstract. As a result of this transformation, words and the concepts implicit in words are abstract even if they designate things as rock or stone. Words evoke reality with a peculiarity: they evoke reality by means of something added to the initial sensation (perception) given to us by our senses once it was transformed into abstract. Words and concepts mean and evoke, that is, they create a particular configuration of the world thus referring to the initial sensation given by our senses. This configuration of the world constitutes what we call reality. Reality is not things in the world manifesting themselves to us, but things evoked by means of the transformation of our sensations into something abstract. Meaning thus is contents of conscience created by cognizant subjects, either individually —all meanings in a particular language initially were formed individually — or by participation of all speakers in what we call the words of a particular language. Words then evoke and mean thus creating new senses whenever a particular word is used, since they represent the synthesis made of sensation, sensibility, receptivity, and the thing added only mentally, intellect, spontaneity.

So our analysis meets with the following difficulty: language does not exist because it is merely a concept created by us in the act of knowing. We cannot verify it really, that is, in anything constituting our world. Language is something in us. Even more: language is necessary for us to make and develop ourselves as human beings. Language is something necessary in two ways: it is necessary for us to make ourselves human (subjective sense). And language is necessary to explain reality, if only to us mentally, thus creating thought (objective sense). Language is necessary for us to understand things surrounding us, understand ourselves and understand that complex reality called language.

\section{Language as it Functions}

On the other hand, we as speakers intuitively know that language functions. Language constitutes the means to create and understand the world, to say something, speak to one another, create and understand thought, make science, survive in the circumstance we are in.

If language functions or not, it constitutes a topic having to do with the degree of reality it may have. The function of something is constituted by the purposes it exists for. In this sense we cannot say that language exists because it functions. It is just the contrary. Language functions because language is somehow real. In human matters, the purpose or aim is the determining thing. Language is created to play a function17. It is necessary to state, first, what its degree of reality is, that is, how far it is real and then to determine if it functions and especially if it performs the functions it was created for. When language functions it fulfils the purposes or aims it was created for. In language human beings are the determining thing. This fact has sense because it states something of human beings. Then, what functions is not language but human beings, who fulfil the aims they created language for.

In effect, human beings achieve their purposes because they speak. So language does not exist because it functions. Language functions because human subjects aim at achieving something. In this sense language is real as well. It is clear thus that language is something when it is used, and something different when it is conceived of. So language is both reality and concept. When language is used, that is, lived by speakers, language is real. However when speakers (and linguists with them) say something of the reality of language, language is a concept, two levels not to be mismatched with each other.

\section{Language as the Result of an Act of Knowing}

The previous distinction has to do with the act of knowing. An act of knowing is nothing but the union of opposites 18, that is, the union of what comes up through our senses and what we create when we want to approximate to things surrounding us. What comes up through our senses is concrete, something we perceive; what we create and add to our perception is mental, that is, something necessarily abstract.

The act of knowing starts with what Aristotle called aisthesis, that is, sensation 19. Sensation, for Aristotle20, is the act of perceiving something as it really is. That is, when we perceive something we confront ourselves to the thing perceived. In this sense the thing perceived is the thing as it is, that is, the real thing. For example, when I eat an orange I perceive the orange as it is. I can feel it is juicy, sweet, pleasantly sour. It is something material being confronted to me who am something material as well and am in a particular circumstance: a human being with the need of eating an orange. The "confrontation" of me with the orange is sensitive, concrete. In this case I do not appreciate some characteristics or notes an orange may have. In the act of eating an orange I do not perceive its colour or its form: these characteristics are

\footnotetext{
17 Cf. Coseriu 1988, pp. 30-31.

18 "Language, cognizant activity, is the union of reason thing $[\ldots], v$ o $\eta \sigma \wedge \varsigma$ $\tau \tilde{\omega} v \dot{\alpha} \delta 1 \varepsilon \rho \grave{\varepsilon} \tau \tilde{\omega} v$, apprehensio indivisibilium" (Coseriu, 1985, p. 55) (my translation).

19 Aristotle, De Anima III, 1, 425a,14, apud Ortega y Gasset 1992a, p. 128. Cf. Martínez del Castillo, 2004, § 2 .

20 For an explanation of aisthesis or sensation cf. Ortega y Gasset, 1992a, p. 129.
} 
of no interest to me in the circumstance I am. That is, I perceive something directly affecting me and only me in some way. As a cognizant subject I do not add anything in the act of eating and thus of perceiving the orange. In that act I shall not use any words or add anything mental to my perception.

So perception is concrete, that is, it is the confrontation of me through my senses with something of the same nature as me. My senses are concrete and can perceive only concretely. Because of this human beings know about the world in a similar way as animals do. In this sense I am nothing but someone living in nature, that is, a natural subject in a natural world, someone affected by the conditions, favourable or unfavourable, imposed on me by nature.

Sensation sometimes, the majority of times, manifests itself through the act of perceiving. Intuition is sensation as well and as such concrete and sensitive. Intuition is a mental state confronting me with reality as it is. In this sense intuition, although concrete and sensitive, goes beyond the concrete character of things. It is just like a sudden flash because of which the cognizant subject has the idea of something in the entire reality it has. It is the mental confrontation of my mind with things in the world thus making them real. The idea felt through intuition is concrete as well: something felt or had in the reality it has. For example, when I play the piano or any instrument or when I drive a car, I'll have a series of intuitions making my decisions, when pulsing keys and making the required movements, reliable. When driving, I turn right or left depending on the things I intuit mentally through my senses. I may turn right or left in accordance with the exact decision intuited in my mind out of my senses. My mind is being directed not by a particular sense of mine but the whole being of me. The decisions I make have to do with the degree of curvature, the rate of speed appropriate to the place, the movement and the circumstances involved. If I turn in a greater or lesser degree of curvature the consequences may be fatal. However, when I drive, I positively ignore what a kind of a thing is that of "the degree of curvature". But I can successfully manage with it intuitively, thus sensitively. The same happens with animals, every one in accordance with the peculiarities of its biological species. A beaver, for example, can manage successfully in cutting trees with the right length it needs to build a dam.

The act of knowing manifesting itself in the speech act (thus constituting language), is prompted by a series of successive intuitions having to do with the thing being conceived of and described; the state of affairs we want to speak of; the thing denoted; the appropriateness, logic and adequacy to the object being described; the circumstances affecting the object being described; the subject making the act of knowing; and the means used to express of all this. The act of knowing as it manifests itself in the speech act is nothing but the fact of human beings living language.

But, as I said before, human subjects have to do something in the circumstance they are involved. They have to tackle with the circumstance they are in, sometimes friendly, sometimes hostile. In this sense human knowledge cannot be based only on aisthesis. Aisthesis or intuition can be executed in two ways: it can be performed sensitively, as animals do. Human beings sometimes perform their intuition, their aisthesis, sensitively, for example, when playing an instrument or driving. Or can aistheisis as well be executed by transforming the initial sensation into something non-sensitive thus adding something new. But the thing to be added cannot be of the same nature as sensation. It must be just the contrary. If sensation is concrete, the thing added is mental, that is, abstract. The cognizant subject then assumes his sensation and transforms it thus making it into abstract. At this point then the character of human knowledge changes thus synthesising sensibility and intellect.

In this discussion, we stated the fact that "people speak" with universal character: all human beings speak. With this, as I said earlier, we made a synthesis of sensibility and intellect based on analogy. But language is necessarily performed in the terms and means of expression of a particular linguistic community. In this sense the concept language is historical: it has been created in a particular speech community in history. Because of this, it is contingent and varies to some extent in the different particular languages. The concept of language in, say, English, is different from the concept referring to the same reality in other languages. In English, "language" is a concept referring to either the universal activity of speaking, executed by all speakers, or the peculiarities of speaking in a particular speech community or a particular or historical language. On the contrary in Romance languages there are two different realities, French langage, Spanish lenguaje, Portuguese linguagem, as distinct from French langue, Spanish lengua, Portuguese lingua. So the concept in English encompasses two different realities. In this sense if we say "language is innate", the expression is ambiguous. Speaking, the activity of speaking is something different from speaking English, French or Portuguese. In these languages there are two different words and two different concepts with different degrees of reality.

Because of this unitary concept of "language" in English, a historical concept belonging to the English language, expressions such as the one just referred to, "language is innate", are the result of this original or 'naïve' conception about language by speakers. The concept of language in this case is something historical, proper of a particular language in question.

\section{Language as it Manifests Itself}

Language does not manifest itself directly; it manifests itself indirectly in something else in different ways.

1. Language manifests itself in the different languages in the world. In this sense language is to be defined in its variety. Because of this we can say that the reality of language is constituted by something going beyond itself. Language is nothing objective, nothing existing in itself.

2. Language exists because human subjects execute a particular activity. Language thus is nothing but the activity of speaking performed by cognizant free and creative subjects. 
3. Language is merely a concept producing a name to something made by human subjects.

The problem then is not to analyse whether language exists or not. It consists in analysing those elements manifesting themselves beyond language: human beings, speakers, on the one hand, languages on the other, and the activity executed by human subjects, on the other.

4. Language manifests itself as well in the idiomatic knowledge of speakers. In this sense language depends on the different traditions in the technique of speaking, that is, languages.

This means that idiomatic knowledge is something different from the tradition in the technique of speaking. Idiomatic knowledge is both individual and participated, that is, common to all speakers of a particular tradition. In this sense language manifests itself incardinated in the different speech communities. Idiomatic knowledge is a set of forms, contents, rules, procedures, attitudes and beliefs in force in a particular speech community (=a language). Language thus is common and historical. It is common since idiomatic knowledge is created daily with the participation of all speakers. Because of this language is historical because it is being made in history, just at the moment when it is spoken.

5. Language manifests itself, as well, in the so-called activity of speaking.

The activity of speaking has to do with language and languages. It involves, as I said before, a subject executing the activity, a product, and a technique. The activity of speaking involves variation, as well. Variation is given in the different periods of the particular language in question. Within the same period or state of the particular language (synchrony), language varies in terms of the place where the particular language is spoken, the social strata or levels of speech, and the different styles of speech. Historically speaking, this variation constitutes different techniques within the same tradition of speaking.

6. On the other hand, language and the activity of speaking manifest themselves in speech acts, the innumerable linguistic acts.

Summing up, language, the concept of "language" and the reality implicit in it cannot be considered as the base to establish a theory for its study. It has not concrete existence. Its degree of reality is the creation of meanings. In this sense it exists but manifesting itself in something else. Language is nothing objective: it is the result of an act of knowing. Language thus is nothing but a series of knots of connections, something created by the human mind.

\section{Language as a Particular Language}

As we said, language does not exist unless in a particular or historical language. Speakers speak and whenever they speak they will speak a particular language 21 . The problem now is to analyse the reality of what we understand as a language or

21 Cf. Coseriu 1992, p. 87. the particular language.

A particular language is the first universal of language 22 since it is the execution of language. This means that particular languages are necessary for the existence of language. In this sense the functioning of any particular language, its elements, forms, contents, rules, procedures, attitudes and beliefs, reveal the nature of language, either if they coincide with ones in other languages or not.

The question now is: can a particular language constitute the base for language study? Can a particular language be considered as the basis for a theory?

Particular languages are not given in themselves. They are the execution of language. The particular language manifests itself as:

1. The idiomatic knowledge of speakers. A language is competence, that is, intuitive knowledge. This knowledge is individual. However, if we verify it in some or many speakers, we can abstract and consider it to be common in a speech community. When speakers speak they will neglect individual and sporadic features. In this sense speakers will select only what is common thus making a language unique.

2. As speech acts or linguistic acts. Speech acts are individual, innumerable and varied thus answering to the needs a particular speaker in a particular context and situation, always aiming at very specific purposes and interests, determined by a particular situation.

3. As techniques of speaking, that is to say, a series of forms, contents, rules, procedures, attitudes and beliefs of speakers thus making possible individual manifold expression. Techniques of speaking function in particular places and territories (determined by the so called diastratic differences), in shorter or larger periods of time (determined by diachronic differences), in different social strata (determined by diastratic differences) and different styles of speech (determined by diaphasic differences $)^{23}$. In this sense we have to distinguish larger techniques of speaking determined by a speech community and lesser techniques of speaking, those determined by a particular territory, a particular social strata or a particular style of speech. The members of these and other speech communities refer to their technique of speaking as a particular language, usually denoted with a proper adjective 24, such as English, German, Russian or the English language, the German language, the Russian language, etc. Lesser techniques of speaking, are those techniques functioning within larger techniques of speaking.

4. As techniques of speaking completely homogeneous thus constituting the so-called functional languages 25 . A functional language is a technique of speaking

\footnotetext{
22 Cf. Coseriu 1987, pp. 155 and ff.

${ }^{23}$ For diatopic, diastratic and diaphasic differences and the contrary, syntopic, synestratic, and symphasic homogeneity, cf. Coseriu 1986b, p. 306.

24 Cf. Coseriu, 1986b, p. 302.

25 Cf. Coseriu, 1992, p. 291.
} 
determined by the speech usually spoken in a particular territory, a particular social strata and a particular style of speech. That is, a functional language is the particular language spoken in a completely homogeneous speech community, a syntopic, synestratic and symphasic language26. In this sense within a speech community (=a particular language) we can distinguish the so-called standard or common language, the functional language usually referred to as the usual one, and exemplary language 27, the functional language referred to by speakers as the model for future performances. Because of this speakers, any speaker, speak several functional languages: for example, formal and informal language, regional speech, the functional language of a particular guild corporation, etc.

5. As attitudes in the way of behaving in the world in order to survive. Because of this, speakers create their individual expression as different from the expression of other speakers belonging to different speech communities. This fact means that language by means of the particular language creates thought, that is, that language is lógos. Because of this when individual speakers create new forms of expression their co-speakers will be able to understand and interpret the new expression, something that may create problems for the speaker of other languages.

6. But logos, however, is not to be attributed to the particular language exclusively, but especially to language. Even within a particular language we can see differences. We have to distinguish two types of lógos: lógos semantikós and lógos apophantikós, that is, meaning in itself and meaning used for specific pragmatic, poetic or scientific purposes. Within this context if we say two plus two is four, we must say that it is correct not because language rules it to be so but because it is something going beyond language 28 .

7. Because of this, speakers of a particular language will think that things are to be said in the way stated in their language. For example, for an old Anglo-Saxon speaker perfective sense of verbs was decisive. In this sense winnan (=gain or attain) was different from ge.winnan (=gain or attain by fighting= conquer). This distinction, as can be seen, was something having to do with the tendencies in the particular language, that is, it was the object of study of the so-called type of the particular language in question. Prefix ge. with verbs, conveyed a perfective sense. In verbs like hieran (=hear) or sēon (=see), ge.hieran, ge.séon, it became redundant to the minds of Middle English speakers, since it merely stressed the meaning conveyed by the verb, but not to old Anglo-Saxons, who considered it necessary for the

\footnotetext{
26 Cf. Coseriu, 1981, pp. 118-120.

27 Coseriu, 1992, p. 164.

28 For the distinction between lógos semantikós and lógos apophantikós, cf. Martínez del Castillo, 2009.
}

expression.

8. And together with this, speakers of a particular community will have ideas, true or false, liable to interpret the world in a particular way. Today it is clear that the sun does not rise or set. However in our daily speech we have to say the sun rises and the sun sets. These ideas, the majority of times, constitute beliefs. This explains how speakers of a particular speech community have similar ideas about the world and things in life and especially in the way of conceiving of things.

As a conclusion, we can say that a particular language is nothing but a set of different aspects manifesting human intelligence and freedom. The particular language exists but in the minds of its speakers as the idiomatic knowledge. As such it is virtual and common, a type of knowledge to be executed in future and prospective performances. In this sense we can really establish a theory on it, but not to study what language is, but to make the description of the first universal of language (for example, the Spanish language or the English language).

This lets us conclude about language. Language is nothing but but a phenomenon, something manifesting itself multifariously in something else. Both language and a particular language are nothing but aspects or sets of connections evincing something previous to them. The thing they evince is the condition of the human mind which is able to reflect about itself in its acting in the world. Language thus is the first revelation of Man29, something invented by human subjects in order to perform themselves in the world and survive in the circumstance they are in.

\section{The Degree of Reality of Speech Acts}

Speech acts exist, have concrete existence, are given at any moment. They constitute concrete realities apt to be verified. Now then, speech acts are very varied and heterogeneous. They deal with innumerable topics and can difficultly be systematized as concrete units. As anything individual, speech acts are given in an anarchic, sporadic, contextual and concrete way. Speech acts as individual, concrete, sporadic, circumstantial and contextual realities, without being referred to a concept giving them unity and reality in some way (language, a particular language, speaking, or speech) and in function of it be explained, will not have any sense at all. Although speech acts have a concrete degree of reality and concrete existence because they can be verified, we shall not be able to study them unless we abstract on them, that is, unless we reduce them to a concept on the one hand, and on the other, we add something to the construct being created either by analogy or pure creation. In order to designate them we are obliged to refer to the concepts of "language" or "speech", calling them linguistic acts or speech acts, that is, acts (=effect of an action or activity [the activity of speaking]) having to do with language or speech (=the effect of the performance of language). Anyway, they mean nothing but the execution of language in any case.

29 Coseriu, 1982, p. 240. 
Speech acts change as well depending on the different traditions in the technique of speaking, either major traditions (languages) or the lesser traditions existing in a particular language, the ones supporting the different functional languages within a particular language (the functional languages of the different territories constituting dialects, the jargons of the different guild corporations, and different styles of speech, defined by diatopic, diastratic and diaphasic features, etc.).

And this is the paradox we are dealing with. Language, a particular language and speaking manifest themselves in speech acts. Now then, speech acts, in spite of the reality they have, need language, a particular language and speaking to be conceived of in what they are and in the reality they manifest. That is, speech acts are determined by language, the particular language and speaking. It is clear then that they all, that is, language, a particular language, speaking and speech acts, are nothing but concepts (effect of the act of knowing), perspectives imposed on the reality they purport, with greater or lesser degree of reality, prompting them all to be considered as something existing. On the other hand, language, a particular language and speaking do not exist but in speech acts. It is clear as well that they all are concepts. None of these realities is autonomous in itself from the point of view of their systematization and conception. They all relate to one another. There will not be language without a particular language, nor will ever be a language without speaking, nor will ever be a speech act without language, a particular language and speaking. They all are linked with one another inexorably. They all together may be considered to constitute a single reality. But if we considered these four realities as constituting one reality, even in this assumption, it would not constitute an autonomous reality. This is the failure of Modern Linguistics30: considering the reality of language (with all its aspects) as something autonomous in itself. Language is nothing autonomous. It cannot be studied in itself. If it was studied in itself the result would be misleading and partial. Language is something relating to human subjects, either considered as a free, creative, contingent, individual, cognizant and historical subject, or as a group of free, creative, contingent, cognizant and historical subjects thus constituting a speech community or a particular or historical language.

When we analyse the activity implicit in speech acts in its entire extent, that is, the activity of speaking in all things it reveals, we shall see that the activity of speaking is as well the result of an act abstraction including in it all aspects studied. In this way language, speaking, and speech acts, designate the same reality.

\section{References}

[1] Chomsky, Noam, New Horizons in the Study of Language and Mind, Oxford University Press, 2000.

30 For example, Ferdinand de Saussure, Edward Sapir, Leonard Bloomfield, Benjamin Lee Whorf, Noam Chomsky, and their followers.
[2] Chomsky, Noam, On Nature and Language, Oxford University Press, 2002.

[3] Coseriu, E., Principios de semántica estructural, Madrid: Gredos, 1981 (1977).

[4] Coseriu, E., Teoría del lenguaje y lingüística general: cinco estudios, Madrid, Editorial Gredos, (1982) [1962].

[5] Coseriu, E., El hombe y su lenguaje. Madrid, Editorial Gredos, 1985 [1977].

[6] Coseriu, E., Introducción a la lingüística, Madrid, Editorial Gredo, 1986a.

[7] Coseriu, E., 1986b, Lecciones de lingüística general. Madrid, editorial Gredos.

[8] Coseriu, E., Gramática, semántica, universales. Estudios de gramática funcional, Madrid: Gredos, 1987 [1978].

[9] Coseriu, E., Sincronía, diacronía e historia: el problema del cambio lingüístico, Madrid: Gredos, 1988 (1956).

[10] Coseriu, E., Competencia lingüística: elementos de la teoría del hablar, Madrid, Editorial Gredos, 1992 [1988].

[11] Coseriu, E. y Ó. Loureda: Lenguaje y discurso, Pamplona, Eunsa, 2006.

[12] Coseriu, E. Lingüística del texto. Introducción a la hermenéutica del sentido, Arco/Libros, 2007 [1973].

[13] Di Cesare, D., Wilhelm von Humboldt y el estudio filosófico de las lenguas, traducción de Ana Agud, Anthropos, 1999.

[14] Heidegger, Martin, El ser y el tiempo, RBA Editores, 2002 [1944].

[15] Humboldt, W., «Ueber die Verschiedenheit des menschlichen Sprachbaues und ihren Einfluss auf die geistige Entwickelung des Menschengesschlechts» trad. Ana Agud: Sobre la diversidad de la estructura del lenguaje humano y su influencia sobre el desarrollo espiritual de la humanidad, Madrid, Anthropos y Ministerio de Educación y Ciencia, (1990) [1836].

[16] Martínez del Castillo, Jesús, La intelección, el significado, los adjetivos, Universidad de Almería, 1999.

[17] Martínez del Castillo, Jesús, La lingüística del decir. El logos semántico y el logos apofántico, Granada: Granada Lingvistica,

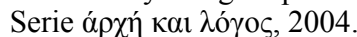

[18] Martínez del Castillo, Jesús, «Hablar, decir y conocer: el acto lingüístico», Oralia, 11 (2008): 375-97.

[19] Martínez del Castillo, Jesús: «El logos semántico y el logos apofántico» Enérgeia I, Online-Zeitschrift für Sprachwissenchaft, Sprachphilosophie und Sprachwissenschaftsgeschichte. 2009: 50-80.

[20] Martínez del Castillo, Jesús: Las relaciones lenguaje-pensamiento o el problema del logos. Madrid: Bilbioteca Nueva, 2010.

[21] Martínez del Castillo, Jesús, Sobre las categorias, Buenos Aires, Deauno.com, 2011.

[22] Martínez del Castillo, Jesús, ed. Eugenio Coseriu (1921-2002) en los comienzos del siglo XXI, 2 vols. in Analecta Malacitana, Anejos/86, 2012.

[23] Martínez del Castillo, Jesús: Psicología, lenguaje y libertad, in Analecta Malacitana, Anejos/89, Universidad de Málaga, 2012. 
[24] Martínez del Castillo, Jesús: Modes of Thinking, Language and Linguistics, in Analecta Malacitana, Anejos/94, 2013, Universidad de Málaga.

[25] Ortega y Gasset, José, Goethe, Dilthey, Alianza Editorial, 1982 (1958). Ortega y Gasset, José, La idea de principio en Leibniz, Alianza Editorial, 1992a [1958].

[26] Ortega y Gasset, José, ¿Qué es conocimiento?, Alianza Editorial, 1992b [1984].

[27] Ortega y Gasset, José, ¿Qué es filosofía?, Alianza Editorial, 1994 [1957].

[28] Ortega y Gasset, José, Sobre la razón histórica, Alianza Editorial, 1996 [1979].

[29] Ortega y Gasset, José, Unas lecciones de metafísica, Alianza editorial, 1999 [1966], pp. 119-120

[30] Ortega y Gasset, José, «El decir de la gente: la lengua. Hacia una nueva lingüística» in $\mathrm{El}$ hombre y la gente, Alianza Editorial, 2001 [1957].
[31] Ortega y Gasset, José, «El decir de la gente: las 'opiniones públicas', las 'vigencias sociales'”. El poder público» in El hombre y la gente, Alianza Editorial, 2001 [1957].

[32] Ortega y Gasset, José, "En torno al coloquio de Darmstadt", in Meditación de la técnica y otros ensayos de ciencia y filosofía, 2002 [1993]: 192-233.

[33] Ortega y Gasset, José, Europa y la idea de nación, Alianza Editorial, 2003 (1996).

[34] Ortega y Gasset, José, "Apuntes para un comentario al banquete de Platón", Obras completas, IX, Taurus, 2009: 729-758.

[35] Popper, Karl, The Logic of Scientific Discovery, London \& New York, Routledge Classics, 2002 [1959). 